\title{
REVIEW
}

\section{Climate and the match or mismatch between predator requirements and resource availability}

\author{
Joël M. Durant ${ }^{1, *}$, Dag Ø. Hjermann ${ }^{1}$, Geir Ottersen ${ }^{1,2,4}$, Nils Chr. Stenseth ${ }^{1,3}$ \\ ${ }^{1}$ Centre for Ecological and Evolutionary Synthesis (CEES), Department of Biology, University of Oslo, PO Box 1066 Blindern, \\ 0316 Oslo, Norway \\ ${ }^{2}$ Institute of Marine Research, Gaustadalléen 21, 0349 Oslo, Norway \\ ${ }^{3}$ Institute of Marine Research, Flødevigen Marine Research Station, 4817 His, Norway \\ ${ }^{4}$ Bjerknes Centre for Climate Research/GEOS, University of Bergen, Allégaten 55, 5007 Bergen, Norway
}

\begin{abstract}
Climate influences a population through a variety of processes, including reproduction, growth, migration patterns and phenology. Climate may operate either directly through metabolic and reproductive processes or indirectly through prey, predators, and competitors. One mechanism that may be particularly important, and which is the focus of this review, is the role of climate in affecting the reproductive success of a predator through its effect on the relative timing of food requirement and food availability during early life stages. This principle - the match or mismatch of predators' requirement with resource availability - originated in the marine literature, where it initially referred to how growth and survival of fish larvae (predator) depends on this production being synchronous with that of their main food items, i.e. early stage zooplankton (prey). Here we review how the match/mismatch hypothesis (MMH) is used to describe climate effects on ecological patterns and processes in both marine and terrestrial systems. In addition to studying match/mismatch sensu stricto, we expand on it to include effects of overall production level and the spatial aspect. Possible impacts of climate change on match/mismatch are examined in the context of one of the most apparent effects of global warming: an advancement of spring phenology. As a consequence of different species reacting dissimilarly, even minor changes in climate may invoke non-linear responses unbalancing established patterns of synchrony. All components of a food chain cannot be expected to shift their phenology at the same rate, and thus are unlikely to remain synchronous.
\end{abstract}

KEY WORDS: Match/mismatch hypothesis · Food chain · Synchrony · Phenology · Recruitment • Timing

\section{INTRODUCTION}

The match/mismatch hypothesis $(\mathrm{MMH})$ seeks to explain recruitment variation in a population by means of the relation between its phenology - the timing of seasonal activities such as flowering or breeding - and that of species at the immediate lower level. The hypothesis states that if the most energy expensive part of the breeding phenology of the higher level (i.e. the predator) occurs at the same time as the peak availabil- ity of the lower level (i.e. the prey), then recruitment will be high: the requirement of the predator matches the availability of resources provided by the prey species. If there is a mismatch between food requirement and food availability, then survival and thus recruitment will be low (see Fig. 1a). In the following we use 'predator' and 'prey' in the broadest sense of the words, including for instance grazers as predators and vegetation as prey. The concept of match/mismatch stems from fisheries biology. In 1914, Johan Hjort adopted the 

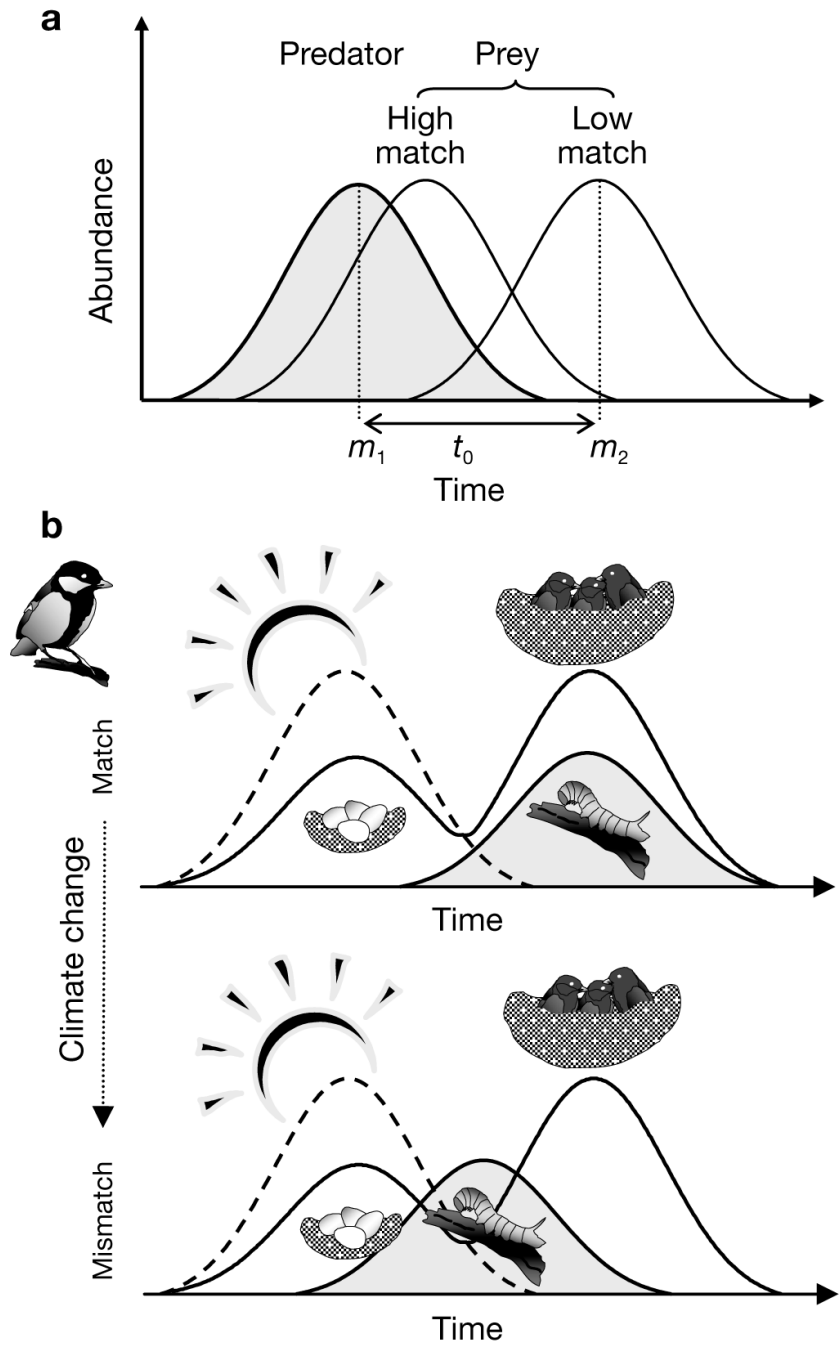

Fig. 1. The match/mismatch hypothesis (MMH). (a) Interaction between 2 trophic levels explained by the MMH. A high match is represented by a temporal overlap of the predator and its prey. An increase in time-lag $\left(t_{0}\right)$ between 2 population peaks $\left(m_{1}, m_{2 i}\right.$ mean peak time for Population 1 and 2, respectively) leads to a low match. Adapted from Cushing (1990). (b) Example of mismatch induced by climate change. The environmental cues (dashed line), triggering onset of egg laying, change in asynchrony to the environmental conditions prevailing when chicks are reared and when birds' energetic demands are highest, as shown for the great tit (Visser et al. 1998). Corrected from Stenseth \& Mysterud (2002)

concept that understanding cod and other fishes' survival at early stages is critical (the Critical Period Hypothesis, Hjort 1914). Hjort's hypothesis postulates that variations in year-class strength mainly resulted from changes in the availability of planktonic food for fish larvae after exhaustion of their yolk supply. The first few days after the yolk sack is consumed - as the fish larvae change from internal to external feeding - is critical, and involves high mortality. David Cushing, who coineed the term 'match/mismatch', expanded on this idea. Because many fish populations in temperate waters spawn at fixed times while the timing of the spring bloom varies according to physical environmental conditions, variability in timing of the peak production of zooplankton prey leads to variability in larval mortality (Cushing 1969, 1990). Variability in mortality may be imposed both because of the vulnerability of first-feeding larvae to starvation or owing to the fact that poorly fed larvae grow slowly and are more susceptible to predation. Since larval mortality is expected to be higher than that at later stages, the larval stage may be the principal determinant of year-class strength (Mertz \& Myers 1994).

The MMH has been much debated among fisheries biologists. It is not easy to demonstrate in the field and several authors have criticized it (Leggett \& DeBlois 1994, Wooton 1998), arguing that a poor match yields poor year classes, while a good match may yield both good and poor year classes, depending on other factors. A number of different hypotheses have been put forward describing mechanisms linking the environment to fish recruitment through survival and growth during early life stages (Table 1). The member/vagrant hypothesis underlines the role of advective losses of eggs and larvae from favourable shelf or bank areas (Sinclair 1988, Sinclair \& Iles 1989), while the migration triangle hypothesis describes how fish must migrate between spatially separate adult feeding grounds, spawning grounds and nursery areas (Harden-Jones 1968). The match/mismatch and migration triangle principles were somewhat more recently united to form the hydrographic containment hypothesis (Cushing 1995).

Even though the $\mathrm{MMH}$ has been contested during the last decades, the importance of trophic/temporal control on larval survival has been supported by several studies (Ellertsen et al. 1989, Fortier et al. 1995, Beaugrand et al. 2003). Recent work by Brander et al. (2001) tested the hypothesis by examining the relationship between modelled production of chlorophyll and copepod eggs, driven by meteorological forcing and cod recruitment. They concluded that the interannual variability in Calanus spp. egg production did have a significant effect on cod recruitment in the Irish Sea and around Iceland. The MMH implies that the effect of a highly variable timing of the production peak of planktonic prey will be counteracted by the fish spreading its spawning effort over a broad temporal window (Mertz \& Myers 1994). This was tested by Mertz \& Myers (1994) who developed a simple larval food supply model and applied it to 11 stocks of Atlantic cod Gadus morhua. They found support for $\mathrm{MMH}$ in the form of a negative correlation between the width of the spawning window and the coefficient of variation $(\mathrm{CV})$ of recruitment. 
Table 1. Alternative hypotheses to explain the impacts of physical environment on early life stages of fish

\begin{tabular}{|c|c|c|}
\hline Hypothesis & Physical features & Biological features \\
\hline $\begin{array}{l}\text { Stable ocean } \\
\text { (Lasker 1975) }\end{array}$ & $\begin{array}{l}\text { Water column stability through weak } \\
\text { local wind stress resulting in } \\
\text { reduced turbulent mixing }\end{array}$ & $\begin{array}{l}\text { Larval feeding success linked to layers with high } \\
\text { concentration of prey items }\end{array}$ \\
\hline $\begin{array}{l}\text { Encounter rate } \\
\text { (Rothschild \& Osborn } \\
\text { 1988, Sundby \& } \\
\text { Fossum 1990) }\end{array}$ & $\begin{array}{l}\text { Small-scale turbulent mixing by } \\
\text { wind and tide }\end{array}$ & $\begin{array}{l}\text { Larval feeding success linked to enhanced contact } \\
\text { rate with zooplankton prey }\end{array}$ \\
\hline $\begin{array}{l}\text { Member/vagrant } \\
\text { (Sinclair \& Iles 1989) }\end{array}$ & $\begin{array}{l}\text { Retentive hydrographic structures } \\
\text { (e.g. gyres, tidally energetic regions) }\end{array}$ & $\begin{array}{l}\text { Limited dispersal of early life-history stages from } \\
\text { favourable distributional area (shelf, bank) }\end{array}$ \\
\hline $\begin{array}{l}\text { Migration triangle } \\
\text { (Harden-Jones 1968) }\end{array}$ & Residual currents & $\begin{array}{l}\text { Spatially separate adult feeding grounds, spawning } \\
\text { grounds and nursery areas between which fish } \\
\text { must migrate }\end{array}$ \\
\hline $\begin{array}{l}\text { Hydrographic containment } \\
\text { (migration triangle and } \\
\text { match/mismatch) } \\
\text { (Cushing 1995) }\end{array}$ & $\begin{array}{l}\text { Residual currents and seasonal } \\
\text { vertical stratification }\end{array}$ & $\begin{array}{l}\text { Spatially separate adult feeding grounds, spawning } \\
\text { grounds and nursery areas between which fish } \\
\text { must migrate, and temporal overlap between fish } \\
\text { larvae and zooplankton prey }\end{array}$ \\
\hline $\begin{array}{l}\text { Optimal environmental } \\
\text { window (Cury \& Roy 1989) }\end{array}$ & $\begin{array}{l}\text { Windiness, turbulence } \\
\text { upwelling intensity }\end{array}$ & $\begin{array}{l}\text { Dome-shaped wind-recruitment relation resulting } \\
\text { from trade-off between food production (limiting } \\
\text { factor when winds weak) and turbulence (limiting } \\
\text { factor when winds strong) in determining larval } \\
\text { feeding success in areas with Ekman-type upwelling }\end{array}$ \\
\hline $\begin{array}{l}\text { Ocean triad (1) } \\
\text { (Bakun 1996) }\end{array}$ & $\begin{array}{l}\text { Enrichment processes: Upwelling, } \\
\text { mixing, cyclonic wind stress curl } \\
\text { (Ekman divergence), cyclonic } \\
\text { eddy formation }\end{array}$ & $\begin{array}{l}\text { More nutrients made available to biological } \\
\text { productivity }\end{array}$ \\
\hline $\begin{array}{l}\text { Ocean triad (2) } \\
\text { (Bakun 1996) }\end{array}$ & $\begin{array}{l}\text { Concentration processes: Convergent } \\
\text { frontal formation, anticyclonic wind } \\
\text { stress curl (Ekman convergence), } \\
\text { lack of dispersion by turbulent- } \\
\text { mixing processes }\end{array}$ & $\begin{array}{l}\text { Enhanced food availability for a predator through } \\
\text { increased concentration of food particles, } \\
\text { 'encounter-rate' increases/decreases as a result of } \\
\text { variability in micro-scale turbulence }\end{array}$ \\
\hline $\begin{array}{l}\text { Ocean triad (3) } \\
\text { (Bakun 1996) }\end{array}$ & $\begin{array}{l}\text { Retention processes: Lack of offshore } \\
\text { transport in (1) Ekman field (near- } \\
\text { surface and superficial layers), } \\
\text { (2) geostrophic current (intermediate } \\
\text { layers), and (3) offshore dispersion } \\
\text { of eddy-like features (filaments) on } \\
\text { the mesoscale; availability of } \\
\text { enclosed gyral circulations, stability } \\
\text { of current patterns to which life } \\
\text { cycles are adapted }\end{array}$ & $\begin{array}{l}\text { Contribute towards keeping individual members of } \\
\text { a population in the appropriate place during the } \\
\text { various parts of the life cycle }\end{array}$ \\
\hline $\begin{array}{l}\text { Oscillating control } \\
\text { (Hunt et al. 2002) }\end{array}$ & $\begin{array}{l}\text { Timing of sea-ice retreat and water } \\
\text { temperatures during spring bloom in } \\
\text { high-latitude seas }\end{array}$ & $\begin{array}{l}\text { Relates decadal-scale changes in climate to alternation } \\
\text { between bottom-up and top-down control of large, } \\
\text { piscivorous fish recruitment in high-latitude seas }\end{array}$ \\
\hline
\end{tabular}

The consequences of match or mismatch for any given population may be highly dependent on its genetic and age structure. If the 'population' in question consists of independent subpopulations, then a total mismatch that wipes out the year class completely is unlikely because, for this to occur, all the subpopulations then would have to fail (Neill et al. 1994). In the case of many commercially exploited fish stocks, fisheries-induced selection pressure has decreased the genetic and age variation, which often leads to spawning becoming more restricted in time and space, thus increasing the risk for a total year class failure (Ottersen et al. 2006).

Originally, the MMH suggested that only the variability of plankton phenology matters because the timing of fish spawning is constant. However, in some fish stocks e.g. Georges Bank haddock (Head et al. 2005), spawning time varies depending on environmental conditions and thus is not consistent with the first tenet of the MMH. However, one can argue that the most important factor is the absolute time lag between the peak of prey production and the peak of predator 
requirement, and then even the variability in the reproduction of stocks such as Georges Bank haddock can be explained by the MMH.

The MMH started with a simple question: why do some fish year classes fail? Similar questions have been posed for non-marine environments. In birds, for example, the 'timing in relation to prey hypothesis' (references in Nilsson 1999) states that in seasonal environments where the availability of prey follows a bell-shaped temporal distribution of short duration, birds must synchronize their breeding with seasonally fluctuating prey populations. This hypothesis, supported by several studies (references in Nilsson 1999), is more or less synonymous with Cushing's (1969) MMH.

Although the $\mathrm{MMH}$ is generally applicable, it is difficult to test. However, a few studies have attempted to test the hypothesis experimentally. For instance, Gotceitas et al. (1996) investigated the MMH by exposing Atlantic cod larvae to 1 of 5 different food treatments (Fig. 2), mimicking the different mismatch possibilities. In short, their results suggest that a mismatch and its timing can significantly influence growth and survival of cod larvae. Also, in birds, some experiments show the usefulness of the $\mathrm{MMH}$ to describe reproductive variation. For example, Nooker et al. (2005) artificially delayed the laying (i.e. increased the degree of mismatch) in tree swallows Tachycineta bicolor, resulting in a decrease in reproductive success.

\section{TEMPORAL MATCHING AND CLIMATE CHANGE}

Global air and sea surface trends experienced during the past century (increases of between 0.4 and $0.8^{\circ} \mathrm{C}$ ) are expected to accelerate in the current century (IPCC 2001, 2007), modifying the phenology of many organisms (e.g. Wuethrich 2000). This em-

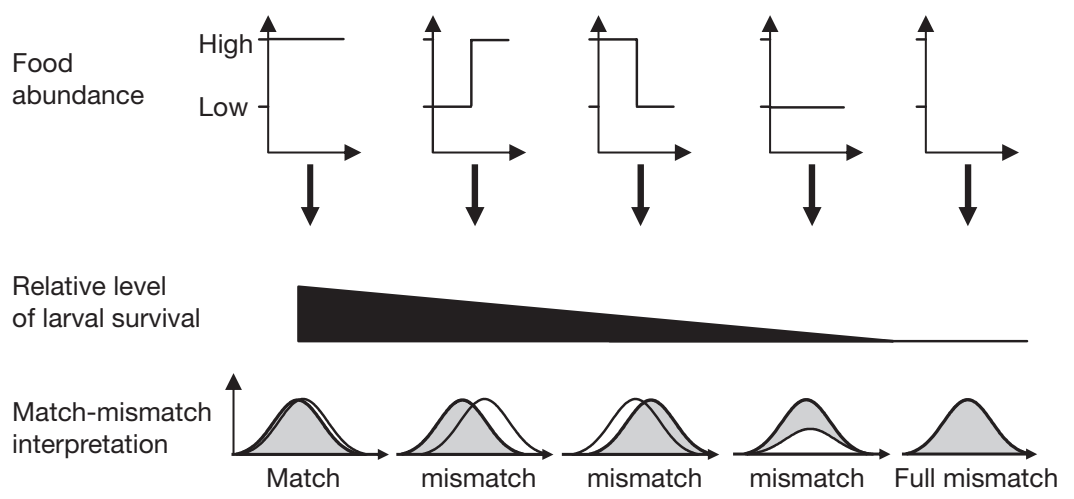

Fig. 2. Experimental example of match/mismatch. Different feeding conditions produce different Atlantic cod larval survival rates (Gotceitas et al. 1996) phasizes the utility of simple hypotheses such as the $\mathrm{MMH}$, which has been used in several studies addressing the effect of climate change on trophic interactions between predator and prey in fish-plankton (Cushing 1990, Ottersen et al. 2001, Beaugrand et al. 2003), insect-plant (Visser \& Holleman 2001) and bird-insect interactions (Thomas et al. 2001, Winkler et al. 2002, Sanz et al. 2003, Visser et al. 2003).

\subsection{Phenology, synchrony and reproduction}

Climate change affects the relative timing of food requirement and food availability for various organisms and by doing so influences their reproduction and survival. Reproduction and survival of a predator depend on its ability to encounter and eat a sufficient quantity of suitable prey to avoid starvation. Differences in the temporal and spatial match between predator and prey thus generate variability in predator survival rates, including interannual variability. Studies of phenology provide some of the strongest evidence for the effects of climate change on organisms (Hughes 2000, Ottersen et al. 2001, Stenseth et al. 2002, Walther et al. 2002, Parmesan \& Yohe 2003, Root et al. 2003, Dunn 2004). In a survey of 677 species of plants and animals, $62 \%$ showed trends toward earlier phenology consistent with a warming climate (Parmesan \& Yohe 2003). A pertinent question is whether predator populations have shifted their reproductive timing sufficiently to match the shift of timing of their main prey species? If not, a mismatch in phenology will arise and the consequences may be severe, including biodiversity loss (Stenseth \& Mysterud 2002, Visser et al. 2004).

If we accept the premise that predators have adapted their phenology to the current climate, climate change can be expected to weaken the synchronization between food availability and the food requirements for the average predator individual (Visser et al. 2004). This effect can be addressed in a $\mathrm{MMH}$ framework. In the literature there are several studies that illustrate the climatic disruption of the synchrony between predator and prey, i.e. passing from a pattern of match to one of mismatch. For example, warmer springs disrupt the otherwise tight and well-known synchrony of oak bud burst Quercus robur and winter moth Operophtera brumata egg hatch (Visser \& Holleman 2001). In the recent warm springs, the winter moth eggs have been hatching up to 3 wk before oak bud burst. 
Because newly hatched moths can only survive a few days without food, this will lead to higher mortality and lower reproductive success.

Rising sea temperatures are affecting the recruitment in bivalves, such as Macoma balthica (Philippart et al. 2003), by advancing their spawning and thus creating a mismatch with the light-dependent phytoplankton bloom. Philippart et al.'s (2003) study (which is one of the few studies on the mechanistic effect of the $\mathrm{MMH}$ on a population) shows that the mortality of M. balthica juveniles has become increasingly densitydependent as the degree of mismatch has increased.

Rutberg (1987) suggested that birth timing and synchrony, as an adaptation to climatic seasonality, should result from the use of cues by animals that can be reliably used to predict future nutritional and weather conditions. As an example, interannual variation in plant phenology induced by e.g. climatic variability has the potential to cause variation in the timing of parturition within populations of caribou (Post \& Stenseth 1999, Post et al. 2003). However, because migratory animals initiate their breeding migration when at the wintering sites, they therefore cannot rely on conditions at the breeding location but must use more global cues. Migratory birds normally arrive at their breeding grounds only shortly before they start breeding, which constrains their ability to anticipate the advancement of their food sources. A disjunction between local and more global cues could pose problems as the asynchrony grows.

Indeed, temperatures (or other weather variables) have not just simply increased with global warming. For example, temperatures change more in some seasons than in others, and differently at different locations (e.g. wintering versus breeding area) (Visser et al. 1998, Inouye et al. 2000, Walther et al. 2002). This means that climate change affects the cues used (the environment of decision making) differently from the environmental variables that affect the timing of favourable conditions (the environment of breeding). This could have a strong effect on the reproduction of migratory birds. For example, with global warming, the American robin Turdus migratorius is arriving earlier at breeding sites in the high-latitude Colorado Rocky Mountains. Because high- and low-latitude areas are not responding similarly to climate change, robins must now wait longer (18 d delay over $19 \mathrm{yr}$ ) for snowfree ground to appear before they can reproduce (Inouye et al. 2000). Although they can seek food at lower elevations while waiting for the snow to melt, resources may be limited here also, and there may therefore come a point when these birds have insufficient food at this time of year.

Many bird species in the UK have advanced their date of egg laying over the past 25 yr (Crick et al.
1997). This pattern is confirmed by long-term studies of a few bird populations (Winkel \& Hudde 1997, McCleery \& Perrins 1998). However, this is not the case for all bird species. For example, while vegetation phenology and caterpillar burst has advanced in the Netherlands over the past decades, the date of egg laying, i.e. hatching, in a great tit Parus major population has not (Visser et al. 1998). In this example, climatic change has caused an overall reduction in fitness by increasing the degree of mismatch (Fig. 1b; see also Buse et al. 1999 for the relationship between the winter moth Operophtera brumata L. and the tits Parus major L. and P. caeruleus L.).

In general, 2 important requirements must be met in order to apply the MMH. Firstly, both predators and prey must present a certain degree of seasonality (e.g. Durant et al. 2005). Secondly, the MMH assumes that the recruitment or survival of predators is limited by their access to prey, i.e. bottom-up control (Cury et al. 2003). In practice, there are many cases where one or both of these assumptions fail. For instance, the survival of Soay sheep lambs Ovies ovies L. was not affected by a temporal mismatch between vegetation peak and average birth date (Durant et al. 2005) because the island where the studied population lives is only weakly seasonal, and vegetation is available all year round (though its quality does vary substantially; Crawley et al. 2004). Furthermore, many species may be limited more by predation, i.e. topdown control. For example, some fish are limited by cannibalism under certain environmental conditions (e.g. walleye pollock; Wespestad et al. 2000, Hunt et al. 2002). Another example is the synchrony or asynchrony between vegetation and birth date of African ungulates, which seems to result more from antipredator adaptations than a resource match (Sinclair et al. 2000).

\subsection{Timing and latitude}

Timing of reproduction in temperate-zone birds is affected by a whole range of cues (Wingfield et al. 1992). The onset of breeding in many temperate-zone species is timed to maximize reproductive success in the face of variable environmental conditions. Among the environmental cues that regulate gonadal development and reproductive function, photoperiod is the main initial predictive factor that opens the reproductive window (time period during which reproduction is possible, as apparent in gonadal activation; Silverin et al. 1993, Wingfield 1993, Gwinner 1996). The strong dependence of bird reproduction on photoperiod, which is invariable for a particular latitude, makes them less plastic to environmental change than other species 
whose reproduction depends on e.g. temperature (see section 2, above, for examples of mismatch between the peaks of abundance of birds and caterpillars).

Seabirds require many resources to produce eggs, and the quality of the eggs produced may affect the survival of chicks (Carey 1996). Obtaining resources for egg production may be particularly difficult when the duration of the breeding season is constrained (Perrins 1996), implying that birds must obtain the necessary resources by a certain date. Consequently, the timing of breeding itself is often dependent upon food availability, meaning that laying date is (by-and-large) correlated with the natural changes in food resources (Meijer \& Drent 1999).

The MMH may be extended to include latitude, thus better covering bird migration changes owing to climate. The earlier onset of spring has consequences for the timing of breeding in birds, which have evolved to match peak food availability (Lack 1968, Visser et al. 2004, Jonzén et al. 2006). We may therefore expect the timing of breeding to track any temporal shift in food availability caused by a trend in spring temperature (Dunn 2004). Most passerine birds breeding in temperate areas of the Northern Hemisphere are seasonal migrants, and the timing of migration ultimately constrains when breeding can begin (Both \& Visser 2001, Both et al. 2006). However, short-distance migrants that spend the winter close to the breeding grounds may be able to adjust the timing of migration in response to local climate change, which will be correlated with the conditions on the breeding grounds.

\section{EXPANDING THE MATCH/MISMATCH CONCEPT}

The food availability for an organism is a complex feature that encompasses both quantity and accessibility of the food resource considered. The MMH essentially deals with accessibility - temporally and spatially. However, we can expect that the relationship described by MMH may vary among years depending on the productivity of the lower trophic level and the spatial change.

\subsection{The role of abundance}

Cushing (1982) indicated that the MMH will be modified by food abundance: 'The production of fish larvae in time should be matched or mismatched to that of their food. If matched, recruitment would be high within the limits of variation of the primary production. If mismatched, recruitment will be low-more so if primary production is low, but less so if it is high'. Since then several studies developed the hypothesis without formally stating it, e.g. Beaugrand et al. (2003).

Gotceitas el al. (1996) stressed the importance of abundance when mimicking the $\mathrm{MMH}$ in the laboratory by changing the pattern of food provisioning (high-low, low-high, low, high food supply) to cod larvae (see Fig. 2a). Durant et al. (2005) explored the recruitment-match/mismatch relationship in relation to food abundance. They found that the change in abundance of predator/prey can disrupt or amplify the phenomenon described by the MMH (Fig. 3). In other words, they found that the temporal synchrony and the food abundance:food requirement ratio should be considered conjointly when exploring the match/ mismatch relationship. Both studies address the topic of climate change. While global warming may disrupt the trophic synchrony (the $\mathrm{MMH}$ ) between predator and prey, it may at the same time increase the primary productivity. As shown by Durant et al. (2005), this increase in food abundance may compensate for the increase in asynchrony. The ability to separate the effect of a within-season temporal shift of trophic synchrony (the $\mathrm{MMH}$ ) from an annual component linked to total food abundance on recruitment will improve our ability to predict whether trophic cascades owing to climate change are likely.

\subsection{Spatial match/mismatch hypothesis}

Although the MMH was initially developed for a situation where temporal variability was the principal concern, factors influencing reproductive success and population dynamics vary in space as well as in time (Chick \& Van Den Avyle 1999). Conceptually, we can suppose that the increase in distance between predator and prey has the same effect as an increase in temporal mismatch. Indeed, an increase in the distance between a predator and their prey will decrease the relative abundance of the latter by reducing overlap. Likewise, for central-place foragers such as seabirds (fixed to 1 place for breeding and radiating from it to forage) an increased distance to the foraging zone decreases the food availability owing to an increase in travel time, even though prey abundance is not changed.

Climate affects the transport processes that in turn influence prey dispersal and recruitment. In other words, climate change will affect the relative location of the coupled predator-prey and increase the degree of spatial mismatch. For instance, striped bass Morone saxatilis is an anadromous species with freshwater larvae that feed on zooplankton. In order for the larvae to grow optimally, they require a good quality of zooplankton, which varies depending on the location 

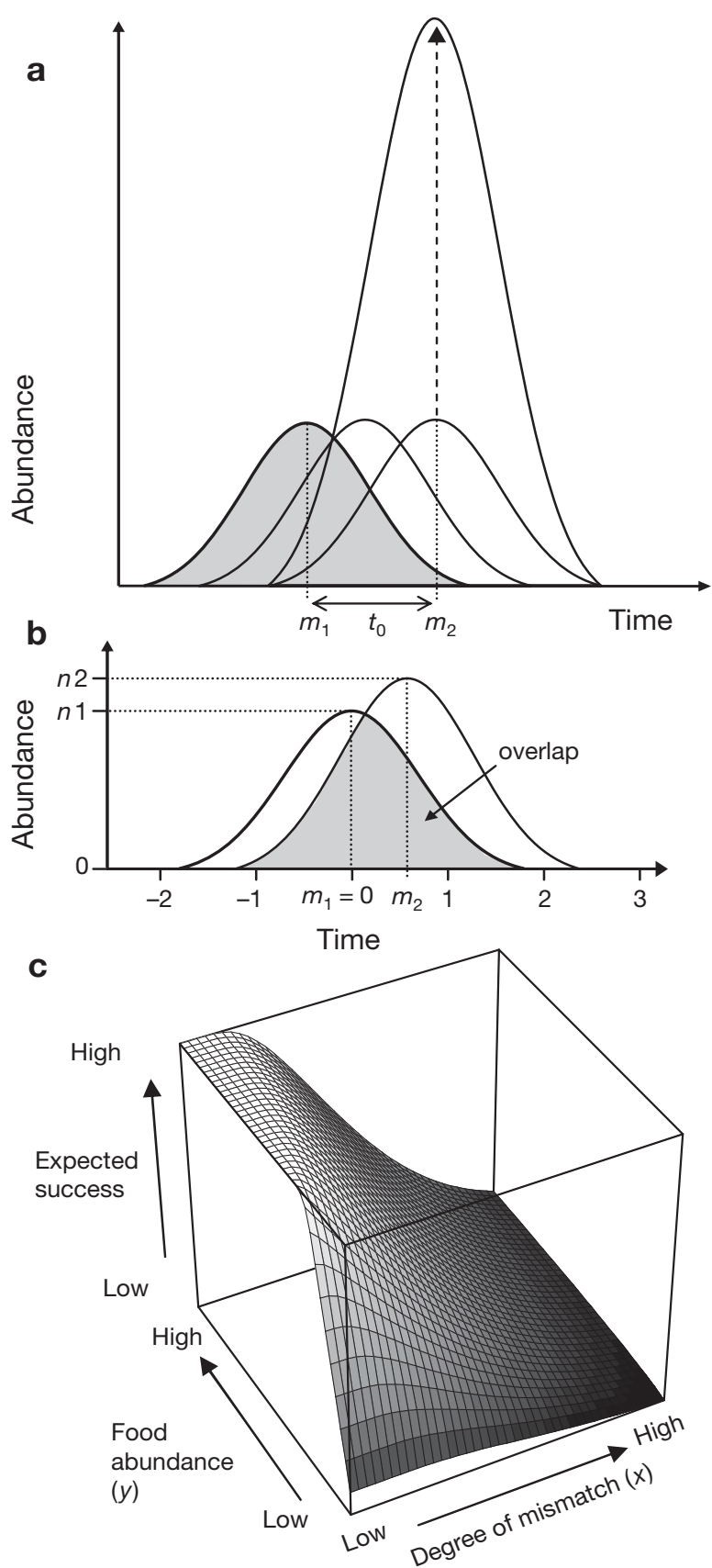

Fig. 3. Match/mismatch and the role of abundance. (a) An increase in time-lag $\left(t_{0}\right)$ between 2 populations leads to a low match: a small or non-existent overlap (predator in grey shade). At the same time, a change in the abundance level (here increase) can disrupt or amplify the phenomena described by the match/mismatch hypothesis. (b) Determination of the optimum overlap of 2 normally distributed populations $\left(y=1 / \sqrt{2} \pi \times \mathrm{SD} \times \mathrm{e}\left[(-t-m)^{2} /\left(2 \mathrm{SD}^{2}\right)\right]\right.$, where $t=$ time, $\mathrm{SD}=$ standard deviation and $m=$ mean peak time). The higher trophic level distribution ( $n 1$ [abundance, see $y$-axis] $=1, m_{1}=0$ and SD1 $=1$ ) is the left curve. The overlap (grey shade) depends on the degree of mismatch $\left(m_{1}-m_{2}\right)$ and difference in abundance $(n 2 / n 1)$. (c) Effect on the reproductive success (overlap) of the changes in degree of mismatch and relative abundance of food for the higher trophic level. Adapted from Durant et al. (2005) (river, lake). Larval striped bass have a greater probability of being matched to suitable prey resources if transported to lentic rather than to riverine or transitional habitats (Chick \& Van Den Avyle 1999). Spawning location, stream flow, and temperature affect larval transport to lentic habitats (spatial match) and all 3 are affected by climate change.

The same phenomenon can be seen in marine systems, e.g. in seabird-fish relationships. During the breeding season, seabirds are typical central-place foragers, tied to a breeding site on land and foraging for marine resources. Seabirds must regularly make foraging trips of hundreds or thousands of kilometres within a period of days (references in Durant et al. 2004a). The distance between the breeding grounds on land and the feeding zones at sea is a major constraint on seabird breeding and can be affected by climate (Weimerskirch \& Cherel 1998). For example, the main prey of breeding Atlantic puffins Fratercula arctica nesting along the Norwegian coast is the Norwegian spring-spawning (NSS) herring Clupea harengus (Durant et al. 2003). This herring stock spawns at various locations along the Norwegian coast (Sætre et al. 2002) and its larvae drift northwards with the Norwegian coastal current toward the Barents Sea (Dragesund 1970). This current splits into 2 branches at about $63^{\circ} 30^{\prime} \mathrm{N}$ : an outer minor branch that follows the continental shelf break, and an inner major branch (Sætre 1999). In addition, the speed of the northward drift varies among years (Sæetre et al. 2002). Hence, the drift pattern of the herring larvae varies from year to year (Sæetre 1999), bringing them closer or further away from the foraging ground of the breeding puffins (Durant et al. 2003, 2005) and thus creating a spatial match or mismatch situation between the puffins and their main prey. In the long-term perspective, climate change is expected to increase the water temperature in the Norwegian Sea (Hassol 2004), and species distributions are predicted to shift to the north (Beaugrand et al. 2002, Hassol 2004) with subsequent effects on seabird populations. This change is already known to have occurred for the Norwegian spring-spawning herring, whose spawning grounds have shifted northwards during the last century (Devold 1963, Holst et al. 2002).

Spatial match/mismatch is important for egg and larval survival of marine fish. The sea is 3-dimensional and resource distribution must be considered as such. For example, the spawning sites for cod in the central and eastern Baltic Sea are located in several deep basins. Successful egg development in these basins depends on physical conditions, especially oxygen content, meaning that the suitable body of water differs among basins and years (MacKenzie et al. 2000). This is suggesting that the spawning stock may sometimes be distributed suboptimally among basins. Also, 
cod eggs in parts of the area (the Bornholm basin) suffer from high predation from clupeids (especially sprat Sprattus sprattus), depending on the vertical overlap between predator and prey. This overlap depends on the presence of certain hydrographic conditions: in periods of water stagnation, clupeids stay higher in the water column to avoid the anoxic bottom layer, overlapping more with cod eggs (Köster et al. 2005). (In this example, the 'resource' from the cod's viewpoint is predator-free space.) A spatial MMH is also relevant for fish larvae, because both spatial and temporal distribution varies greatly for zooplankton (e.g. Betsill \& Van Den Avyle 1997, Chick \& Van Den Avyle 1999).

For seabirds, one must add depth to horizontal distribution of prey when studying the effect of distance to the nest. As an example, telemetric studies showed that the King Penguin Aptenodytes patagonica prefers to exploit the polar front located 340 to $450 \mathrm{~km}$ to the south of their breeding site, and dive to the depth of the thermocline where prey is concentrated (Charrassin \& Bost 2001). Climate affects the position of both the polar front and the depth of the thermocline, thus changing the distance to the foraging ground for the penguin. When this distance is increased, it creates a mismatch situation with negative impact on the penguins' reproductive success.

The spatial overlap between resources and predator is thus a crucial element of successful reproduction, and represents a very important new area of research. Recently, a lot of attention has been given to the topics of water mass advection (e.g. Sundby 2000), spatial variation in survival (e.g. Ciannelli et al. 2007) and bird migration (e.g. Jonzén 2006) in relation to climate. These studies may be the starting point from which to study the impact of spatial distribution of resources on recruitment (see e.g. Ciannelli \& Bailey 2005).

\subsection{An ecosystem approach}

The MMH may be at play not only between tertiary and secondary producers, like first-feeding fish larvae and zooplankton nauplii, but also between other neighbouring trophic levels. In pelagic ecosystems, algae-zooplankton interactions form the basis for energy flux to higher trophic levels (Platt et al. 2003). In temperate marine environments, the recruitment success of higher trophic levels is highly dependent on synchronization with pulsed planktonic production (Edwards \& Richardson 2004). Thus, a decoupling of such adapted predator-prey relationship, for instance owing to climate change, is likely to be transmitted upwards to all trophic levels, possibly causing drastic ecological consequences (Winder \& Schindler 2004). Such climate-induced changes have taken place in the North Sea (Edwards \& Richardson 2004). The responses were found to differ throughout the seasonal cycle and among species within the same functional group, leading to increasing levels of mismatch as the synchrony of peak production between successive trophic levels began to decay. Similar disruptions in the trophic linkages were found in the completely different environment of Lake Washington (USA). Here, a long-term decline in the keystone herbivorous Daphnia pulicaria populations has been associated with an expanding temporal mismatch with the spring diatom bloom that has advanced by more than $20 \mathrm{~d}$ since 1962 owing to climate change (Winder \& Schindler 2004). In an Arctic marine environment, the timing of the ice retreat affects the phytoplankton bloom both in time and space (Hunt et al. 2002). In some years the bloom occurs early in cold waters, and in other years late in warmer waters. Zooplankton, the main food resource for many pelagic fish species, is spatially coupled to phytoplankton and affected by sea temperature. Consequently, fish productivity and to some extent piscivorous marine birds (Croxall et al. 2000) and mammals are expected to depend on the timing of ice retreat.

Top predators depend on their prey, which in turn depend on a lower trophic level such as plankton. If we consider the whole trophic chain instead of only one predator and its prey, we can obtain a better picture of the ecosystem functioning and the $\mathrm{MMH}$ effect on it. A recent study on seabirds showed that the timing of reproduction of the Atlantic puffin is adjusted to food abundance and climate variability (Durant et al. 2004b), and that this timing to some extent affects the reproductive success (Durant et al. 2005). Durant et al. (2005) described a very simple pattern by focusing mainly on the puffin and its prey. However, the scope can be broadened (Fig. 4) by adding a lower trophic component: i.e. the plankton. The NSS herring that forms the principal prey for Røst puffins is the same population used by Cushing (1990) to test his MMH. We are now in the position to explain the herring abundance by either match or mismatch with the plankton on the Norwegian coast and thus complete the pattern (Fig. 4). Indeed, when looking at relationships between climate and breeding, Durant et al. (2006) showed that the main climate effect on puffin reproduction is detected at the level of the herringplankton relationship.

\section{DISCUSSION AND CONCLUSIONS}

The MMH was developed to explain recruitment variation in fish. It is therefore not surprising that the MMH has been applied most often to marine systems, whatever the levels of the trophic chain con- 


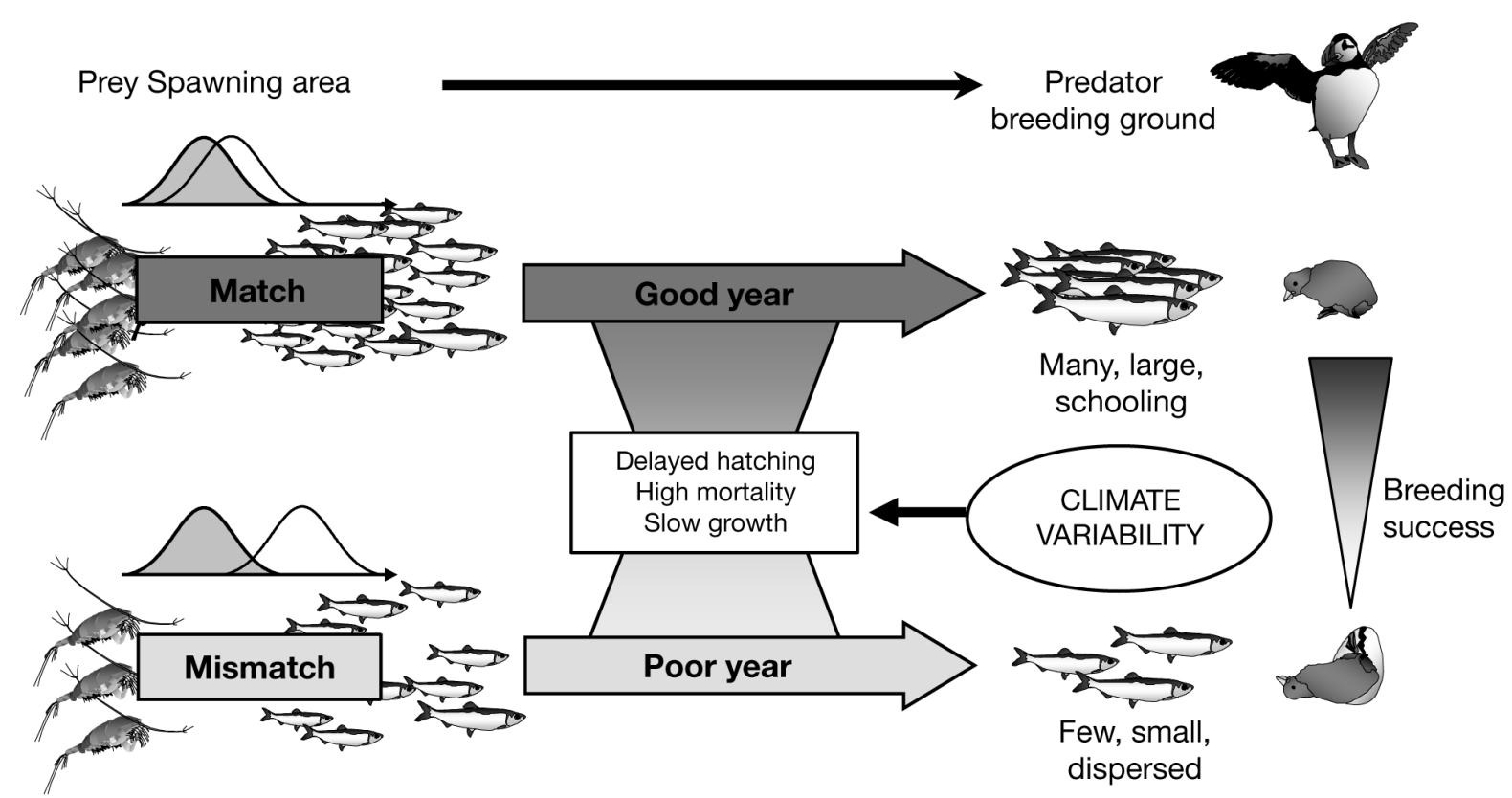

Fig. 4. Ecosytem match/mismatch. The relationship between herring and plankton follows a match/mismatch pattern. While the timing between reproduction of puffin at Røst and that of herring can match, plankton may have been a limiting factor for herring reproduction at the spawning area. Adding 1 trophic level adds complexity to the system (see Fig. 3). In other words, an observed mismatch situation can be the result of another at a lower trophic level

sidered. In this review we summarized examples of $\mathrm{MMH}$ between phytoplankton-zooplankton, planktonbivalve, and plankton-fish. In terrestrial systems the best examples of $\mathrm{MMH}$ are found among birds. Indeed, an abundant literature can been found on the subject, especially in relation to climate change. In contrast, there is to our knowledge no such thing as a mach-mismatch effect in, for example, lizards. Being typical generalists in what they eat, lizards do not depend on the peak of 1 prey resource. For lizards, the ambient temperature can be more significant than synchrony with 1 food resource for determining reproduction and performing other activities (i.e. in order to maintain body temperatures above the threshold required for reproduction). In mammals, the use of $\mathrm{MMH}$ is even more difficult. Mammalian females usually accumulate body reserves in preparation for winter. Immediately after birth, the survival of the young partly depends on energy from lactation. It is then through the mother, and her use of body reserves and/or access to food, that the environment affects the survival of the young. This will create a buffer and make it very difficult to detect a $\mathrm{MMH}$ pattern. However, the situation after weaning may lead to match or mismatch. For example, pinnipeds are central-place foragers during breeding, and post-weaning survival will depend on the food resources close to the natal rookery (Rutishauser et al. 2004). Indeed, the body reserves accumulated during the lactation period must serve both for thermoregulation and energy supply until first feeding.
Table 1 summarizes alternative hypotheses to explain, for the marine environment, how physical processes may determine the availability of food for the growth/development/survival needs of a predator. However, for terrestrial systems such a summary seems more difficult. Before weaning/fledging, both terrestrial and marine young mammals and birds are generally not free-ranging and depend on parental care. Food availability is thus never due directly to the increase of the chance meeting with food, as described by e.g. the encounter-rate hypothesis. However, most of the hypotheses described in Table 1 can still be applied. For example, seabirds are known to concentrate their foraging in oceanic fronts (Hunt 1990, Schneider 1990) at the boundaries of water masses, ice edges and currents, which interact with bathymetry and may all concentrate prey. This is not very different from the ocean triad hypothesis described by Bakun (1996).

As seen from the examples above, it is clear that the degree of both temporal and spatial overlap between the seasonal peak of predator and prey production is crucial for the recruitment of the predator. Table 2 summarizes the climate variables affecting the timing of predator and prey for some predator-prey couplings, and shows that the mismatch pattern results from predator and prey having different responses to the environment. In all cases of decoupling following climate change, the timing of predator and prey were not affected by the same climatic variable. In cases when the synchrony was maintained, both predator and prey 
Table 2. Environmental variable affecting timing of predator-prey coupling

\begin{tabular}{|c|c|c|c|}
\hline \multirow[t]{2}{*}{ Predator-prey } & \multicolumn{2}{|c|}{ Variable affecting timing } & \multirow[t]{2}{*}{ Source } \\
\hline & Predator & Prey & \\
\hline American robin-earthworm & Temperature & Temperature & Inouye et al. (2000) \\
\hline Bivalve-phytoplankton & Temperature & Photoperiod & Philippart et al. (2003) \\
\hline Cod-copepod & Constant & Temperature & Beaugrand et al. (2003), Ottersen et al. (2006) \\
\hline Fish-plankton & Constant & Wind, mixing etc. & Cushing (1990) \\
\hline Flycatcher-caterpillar & $\begin{array}{l}\text { Endogenous } \\
\text { rhythm }\end{array}$ & Temperature & $\begin{array}{l}\text { Both \& Visser (2001), Sanz et al. (2003), } \\
\text { Both et al. (2006) }\end{array}$ \\
\hline Haddock-phytoplankton & $\begin{array}{l}\text { Broad-scale } \\
\text { environmental } \\
\text { pressure }\end{array}$ & Photoperiod & Platt et al. (2003) \\
\hline Threadfin shad-zooplankton & Wide hatching & Temperature & Betsill \& Van Den Avyle (1997) \\
\hline Tit-caterpillar winter moth & Selection pressure & Temperature & $\begin{array}{l}\text { Visser et al. (1998), Buse et al. (1999), } \\
\text { Thomas et al. (2001), Visser et al. (2003) }\end{array}$ \\
\hline Winter moth-oak & Extreme temperature & Temperature & Visser \& Holleman (2001) \\
\hline Zooplankton-phytoplankton & Temperature & Photoperiod & Edwards \& Richardson (2004) \\
\hline Caribou-vegetation & General weather & Snowmelt & Post et al. (2003) \\
\hline Daphnia-diatom & Photoperiod & Temperature & Winder \& Schindler (2004) \\
\hline Crab-bivalve & Winter temperature & $\begin{array}{l}\text { Temperature, } \\
\text { food abundance etc. }\end{array}$ & Strasser \& Günther (2001) \\
\hline
\end{tabular}

timing were following the same environmental variable. In other words, the MMH will apply only to predator-prey pairs that rely on different environmental cues for their phenology. Where the $\mathrm{MMH}$ applies, the predator reproduction timing was constant, i.e. dependent on environmental variables that do not change among years (i.e. photoperiod). As a consequence, their reproduction was fixed in time and only the prey timing fluctuated in relation to the predator's optimal window.

In addition to synchrony in time, food abundance plays a major role in terms of both a quantity effect and an increase in the encounter rate (Durant et al. 2005). Absolute prey abundance can disrupt or amplify the phenomenon described by the MMH. This can lead to situations when there is a match in time and space but the predator reproduction is unsuccessful owing to lack of food, and to mismatch situations where the predator reproduction is nevertheless good. The latter situation is likely to become frequent in the near future because global warming will in many cases increase both the occurrence rate of temporal mismatch and overall primary production, hence food abundance. In contrast, we may expect that with regard to spatial overlap (or lack of it) between predator and prey, there is a threshold under which the recruitment, even during periods of temporal match, can be greatly reduced (Durant et al. 2005).

Increasingly, evidence shows that climate change is leading to differential changes in the breeding dates and timing of maximum food abundance. The breeding date may be too late (e.g. Visser et al. 2004) or too early (Cresswell \& McCleery 2003) for the young predator to make optimal use of the food peak. In the future, we need to examine whether the disruption of synchrony between predator and prey owing to climate change will be maintained. This depends on the capacity of the species to adjust their phenology to climate change and - in the long run - on natural selection of the predator, leading to a reduction in the degree of mismatch through changes at the population level. We also need to know more about the consequences of changes in phenology and how much the decoupling of the predator-prey relationship is/will be transmitted to all trophic levels. For example, severe winters are decoupling the larvae of the crab Carcinus maenas from its bivalve prey. This mismatch situation for the crab accounts for enhanced bivalve recruitment following severe winters in the coastal North Sea (Strasser \& Günther 2001). Likewise, the long-term decline in the keystone herbivorous populations in Lake Washington associated with an expanding temporal mismatch (Winder \& Schindler 2004) will certainly have crucial effects on the ecosystem.

Finally, as a consequence of climate change, in the future we must get used to a world where our hardacquired knowledge on ecosystem and trophic interactions - the result of years of study on a system - is no longer accurate, or at least not reliably so.

It is important to realize that climate change will, in any given location, affect different species - and different trophic levels - differently: this is the domain of the traditional $\mathrm{MMH}$. Climate change will also affect the spatial distribution of different species differently: this is the domain of the spatial analogue of the $\mathrm{MMH}$ as presented in this review. We are convinced that the $\mathrm{MMH}$ will help us to focus our ideas and observations in relation to climate change. 
Acknowledgements. Funding was provided by the Nordic Council through the Nordic Centre of Excellence EcoClim, and the Norwegian Research Council (J.M.D. thanks the 'Biologisk Mangfold' programme for supporting the MADIMA project, and G.O. the 'KlimaEffekter' for supporting the CLIMAR project); further funding was provided by VISTA (www.vista.no) to D.Ø.H. Comments provided by 3 anonymous reviewers on an earlier version of this contribution are greatly appreciated.

\section{LITERATURE CITED}

Bakun A (1996) Patterns in the ocean: ocean processes and marine population dynamics. University of California, San Diego, CA and Centro de Investigaciones Biológicas de Noroeste, La Paz

Beaugrand G, Reid PC, Ibanez F, Lindley JA, Edwards M (2002) Reorganization of the North Atlantic marine copepod biodiversity and climate. Science 296:1692-1694

Beaugrand G, Brander K, Lindley JA, Souissi S, Reid PC (2003) Plankton effect on cod recruitment in the North Sea. Nature 426:661-664

Betsill RK, van Den Avyle MJ (1997) Effect of temperature and zooplankton abundance on growth and survival of larval threadfin shad. Trans Am Fish Soc 126:999-1011

Both C, Visser ME (2001) Adjustment to climate change is constrained by arrival date in a long-distance migrant bird. Nature 411:296-298

Both C, Bouwhuis S, Lessels CM, Visser ME (2006) Climate change and population declines in a long-distance migratory bird. Nature 441:81-83

Brander KM, Dickson RR, Shepherd JG (2001) Modelling the timing of plankton production and its effect on recruitment of cod (Gadus morhua). ICES J Mar Sci 58:962-966

Buse A, Dury SJ, Woodburn RJW, Perrins CM, Good JEG (1999) Effects of elevated temperature on multi-species interactions: the case of pedunculate oak, winter moth and tits. Funct Ecol 13:74-82

Carey C (1996) Female reproductive energetics. In: Carey C (ed) Avian energetics and nutritional ecology. Chapman \& Hall, New York, p 324-374

Charrassin JB, Bost CA (2001) Utilisation of the oceanic habitat by king penguins over the annual cycle. Mar Ecol Prog Ser 221:285-297

Chick JH, Van Den Avyle MJ (1999) Zooplankton variability and larval striped bass foraging: evaluating potential match/mismatch regulation. Ecol Appl 9819:320-334

Ciannelli L, Bailey KM (2005) Landscape dynamics and resulting species interactions: the cod-capelin system in the southeastern Bering Sea. Mar Ecol Prog Ser 291: 227-236

Ciannelli L, Dingsør GE, Bogstad B, Ottersen G, Chan KS, Gjøsæter H, Stenseth NC (2007) Spatial anatomy of species survival rates: effects of predation and climate-driven environmental variability. Ecology (in press)

Crawley MJ, Albon SD, Bazely DR, Milner JM, Pilkington JG, Tuke AL (2004) Vegetation and sheep population dynamics. In: Clutton-Brock TH, Pemberton JM (eds) Soay sheep: dynamics and selection in an island population. Cambridge University Press, Cambridge, p 89-112

Cresswell W, McCleery R (2003) How great tits maintain synchronization of their hatch date with food supply in response to long-term variability in temperature. J Anim Ecol 72:356-366

Crick HQP, Dudley C, Glue DE (1997) Long-term trends towards earlier egg-laying by UK birds. Nature 388:526
Croxall JP, Trathan PN, Murphy EJ (2002) Environmental change and Antarctic seabird populations. Science 297: 1510-1514

Cury P, Roy C (1989) Optimal environmental window and pelagic fish recruitment success in upwelling areas. Can J Fish Aquat Sci 46:670-680

Cury P, Shannon L, Shin YJ (2003) The functioning of marine ecosystems: a fisheries perspective. In: Sinclair M, Valdimarsson G (eds) Responsible fisheries in the marine ecosystem. FAO, Rome and CABI Publishing, Wallingford, p 103-123

Cushing DH (1969) The regularity of the spawning season of some fishes. J Cons Int Explor Mer 33:81-92

Cushing DH (1982) Climate and fisheries. Academic Press, London

Cushing DH (1990) Plankton production and year-class strength in fish populations: an update of the match/mismatch hypothesis. Adv Mar Biol 26:249-293

Cushing DH (1995) Population production and regulation in the sea: a fisheries perspective. Cambridge University Press, Cambridge

Devold F (1963) The life history of the Atlanto-scandian herring. Rapp Proc Verb Cons Int Explor Mer 154:98-108

Dragesund O (1970) Distribution, abundance and mortality of young and adolescent Norwegian spring spawning herring (Clupea harengus Linne) in relation to subsequent yearclass strength. Fiskeridir Skr Ser Havunders 15:451-556

Dunn P (2004) Breeding dates and reproductive performance. Adv Ecol Res 35:69-87

Durant JM, Anker-Nilssen T, Stenseth NC (2003) Trophic interactions under climate fluctuations: the Atlantic puffin as an example. Proc R Soc Lond B 270:1461-1466

Durant JM, Stenseth NC, Anker-Nilssen T, Harris MP, Thompson P, Wanless S (2004a) Marine birds and climate fluctuation in North Atlantic. In: Stenseth NC, Ottersen G, Hurrell JW, Belgrano A (eds) Marine ecosystems and climate variation: the North Atlantic. Oxford University Press, Oxford, p 95-105

Durant JM, Anker-Nilssen T, Hjermann DØ, Stenseth NC (2004b) Regime shifts in the breeding of an Atlantic puffin population. Ecol Lett 7:388-394

Durant JM, Hjermann DØ, Anker-Nilssen T, Beaugrand G, Mysterud A, Pettorelli N, Stenseth NC (2005) Timing and abundance as key mechanisms affecting trophic interactions in variable environments. Ecol Lett 8:952-958

Durant JM, Anker-Nilssen T, Stenseth NC (2006) Ocean climate prior to breeding affects the duration of the nesting period in the Atlantic puffin. Biol Lett 2:628-631

Edwards M, Richardson AJ (2004) Impact of climate change on marine pelagic phenology and trophic mismatch. Nature 430:881-884

Ellertsen B, Fossum P, Solemdal P, Sundby S (1989) Relation between temperature and survival of eggs and first feeding larvae of northeast Arctic cod (Gadus morhua L.). Rapp p-v Réun Cons Int Explor Mer 191:209-219

Fortier L, Ponton D, Gilbert M (1995) The match/mismatch hypothesis and the feeding success of fish larvae in icecovered south eastern Hudson Bay. Mar Ecol Prog Ser 120: $11-27$

Gotceitas V, Puvanendran V, Leader LL, Brown JA (1996) An experimental investigation of the 'match/mismatch' hypothesis using larval Atlantic cod. Environ Biol Fish 130:29-37

Gwinner E (1996) Circannual clocks in avian reproduction and migration. Ibis 138:47-63

Harden-Jones FR (1968) Fish migration. Edward Arnold, London 
Hassol SJ (2004) ACIA, impacts of a warming Arctic: Arctic climate impact assessment. Cambridge University Press, Cambridge

Head EJH, Brickman D, Harris LR (2005) An exceptional haddock year class and unusual environmental conditions on the Scotian Shelf in 1999. J Plankton Res 27:597-602

Hjort J (1914) Fluctuations in the great fisheries of Northern Europe viewed in the light of biological research. Rapp p-v Réun Cons Int Exp Mer 20:1-228

Holst JC, Dragesund O, Hamre J, Misund OA, Østvedt OJ (2002) Fifty years of herring migration in the Norwegian Sea. ICES Mar Sci Symp 215:352-360

Hughes L (2000) Biological consequences of global warming: is the signal already apparent. Trends Ecol Evol 15:56-61

Hunt G (1990) The pelagic distribution of marine birds in a heterogeneous environment. Polar Res 8:43-54

Hunt GL, Stabeno P, Walters G, Sinclair E, Brodeur RD, Napp JM, Bond NA (2002) Climate change and control of the southeastern Bering Sea pelagic ecosystem. Deep-Sea Res II 49:5821-5853

Inouye DW, Barr B, Armitage KB, Inouye BD (2000) Climate change is affecting altitudinal migrants and hibernating species. Proc Natl Acad Sci USA 97:1630-1633

IPCC (2001) Third assessment report of the Intergovernmental Panel on Climate Change. Cambridge University Press, Cambridge

IPCC (2007) Climate change 2007: the physical science basis. Summary for policy makers. Contribution of Working Group I to the Fourth Assessment Report of the Intergovernmental Panel on Climate Change, Cambridge University Press, Cambridge

Jonzén N, Lindén A, Ergon T, Knudsen E and 13 others (2006) Rapid advance of spring arrival dates in long-distance migratory birds. Science 2006 312:1959-1961

Köster FW, Möllmann C, Hinrichsen HH, Wieland K and 10 others (2005) Baltic cod recruitment-the impact of climate variability on key processes. ICES J Mar Sci 62: 1408-1425

Lack D (1968) Ecological adaptations for breeding in birds. Methuen, London

Lasker R (1975) Field criteria for the survival of anchovy larvae: the relation between inshore chlorophyll maximum layers and succesfull first feeding. Fish Bull 73: $847-855$

Leggett WC, Deblois E (1994) Recruitment in marine fishes: Is it regulated by starvation and predation in the egg and larval stages? Neth J Sea Res 32:119-134

MacKenzie BR, Hinrichsen HH, Plikshs M, Wieland K, Zezera AS (2000) Quantifying environmental heterogeneity: habitat size necessary for successful development of cod Gadus morhua eggs in the Baltic Sea. Mar Ecol Prog Ser 193:143-156

McCleery RH, Perrins CM (1998) ... temperature and egglaying trends. Nature 391:30-31

Meijer T, Drent R (1999) Re-examination of the capital and income dichotomy in breeding birds. Ibis 141:399-414

Mertz G, Myers R (1994) Match/mismatch predictions of spawning duration versus recruitment variability. Fish Oceanogr 3:236-245

Neill WH, Miller JM, Vanderveer HW, Winemiller KO (1994) Ecophysiology of marine fish recruitment-a conceptual framework for understanding interannual variability. Neth J Sea Res 32:135-152

Nilsson JA (1999) Fitness consequences of timing of reproduction. In: Adams NJ, Slotow RH (eds) Proc 22nd Int Ornithol Congr. BirdLife South Africa, Durban, Johannesburg, p 234-247
Nooker JK, Dunn PO, Whittingham LA (2005) Effects of food abundance, weather, and female condition on reproduction in three swallows (Tachycineta bicolor). Auk 122: $1225-1238$

Ottersen G, Planque B, Belgrano A, Post E, Reid P, Stenseth NC (2001) Ecological effects of the North Atlantic Oscillation. Oecologia 128:1-14

Ottersen G, Hjermann D, Stenseth NC (2006) Changes in spawning stock structure strengthens the link between climate and recruitment in a heavily fished cod stock. Fish Oceanogr 15:230-243

Parmesan C, Yohe G (2003) A globally coherent fingerprint of climate change impacts across natural systems. Nature 421:37-42

Perrins CM (1996) Eggs, egg formation and the timing of breeding. Ibis 138:2-15

Philippart CJM, van Aken HM, Beukema JJ, Bos OG, Cadée GC, Dekker R (2003) Climate-related changes in recruitment of the bivalve Macoma baltica. Limnol Oceanogr 48: $2171-2185$

Platt T, Fuentes-Yaco C, Frank KT (2003) Spring algal bloom and larval fish survival. Nature 423:398-399

Post E, Stenseth NC (1999) Climatic variability, plant phenology, and northern ungulates. Ecology 80:1322-1339

Post E, Bøving PS, Pedersen C, MacArthur MA (2003) Synchrony between caribou calving and plant phenology in depredated and non-depredated populations. Can J Zool 81:1709-1714

Root TL, Price JT, Hall KR, Schneider SH, Rosenzweig C, Pounds JA (2003) Fingerprints of global warming on wild animals and plants. Nature 421:57-60

Rothschild BJ, Osborn TR (1988) Small scale turbulence and plankton contact rates. J Plankton Res 10:465-474

Rutberg AT (1987) Adaptative hypothesis of birth synchrony in ruminants: an interspecific test. Am Nat 130: $692-710$

Rutishauser MR, Costa DP, Goebel ME, Williams TM (2004) Ecological implications of body composition and thermal capabilities in young Antarctic fur seals (Arctocephalus gazella). Physiol Biochem Zool 77:669-681

Sætre R (1999) Features of the central Norwegian shelf circulation. Cont Shelf Res 19:1809-1831

Sætre R, Toresen R, Søiland H, Fossum P (2002) The Norwegian spring-spawning herring - spawning, larval drift and larval retention. Sarsia 87:167-178

Sanz JJ, Potti J, Moreno J, Merino S, Frias O (2003) Climate change and fitness components of a migratory bird breeding in the Mediterranean region. Global Change Biol 9: 112

Schneider D (1990) Seabirds and fronts: a brief overview. Polar Res 8:17-21

Silverin B, Massa R, Stokkan KA (1993) Photoperiodic adaptation to breeding at different latitudes in great tits. Gen Comp Endocrinol 90:14-22

Sinclair M (1988) Marine populations. An essay on population regulation and speciation. University of Washington Press, Seattle

Sinclair M, Iles TD (1989) Population regulation and speciation in the oceans. J Cons Int Explor Mer 45:165-175

Sinclair ARE, Mduma SAR, Arcese P (2000) What determines phenology and synchrony of ungulate breeding in Serengeti? Ecology 81:2100-2111

Stenseth NC, Mysterud A (2002) Climate, changing phenology, and other life history traits: Nonlinearity and matchmismatch to environment. Proc Natl Acad Sci USA 99: 13379-13381

Stenseth NC, Mysterud A, Ottersen G, Hurrell JW, Chan KS, 
Lima M (2002) Ecological effects of climate fluctuations. Science 297:1292-1296

Strasser M, Günther CP (2001) Larval supply of predator and prey: temporal mismatch between crabs and bivalves after a severe winter in the Wadden Sea. J Sea Res 46: $57-67$

Sundby S (2000) Recruitment of Atlantic cod stocks in relation to temperature and advection of copepod populations. Sarsia 85:277-298

Sundby S, Fossum P (1990) Feeding conditions of Arcto-Norwegian cod larvae compared with the Rothschild-Osborn theory on small-scale turbulence and plankton contact rates. J Plankton Res 12:1153-1162

Thomas DW, Blondel J, Perret P, Lambrechts MM, Speakman JR (2001) Energetic and fitness costs of mismatching resource supply and demand in seasonally breeding birds. Science 291:2598-2600

Visser M, Holleman L (2001) Warmer springs disrupt the synchrony of oak and winter moth phenology. Proc R Soc Lond B 268:289-294

Visser ME, van Noordwijk AJ, Tinbergen JM, Lessells CM (1998) Warmer springs lead to mistimed reproduction in great tits (Parus major). Proc R Soc Lond B 265:1867-1870

Visser ME, Adriaensen F, Van Balen J, Blondel J and 10 others (2003) Variable responses to large-scale climate change in european Parus populations. Proc R Soc Lond B 270:367-372

Visser ME, Both C, Lambrechts MM (2004) Global climate change leads to mistimed avian reproduction. Adv Ecol Res 35:89-110

Walther GR, Post E, Convey P, Menzel A and 5 others (2002)

Editorial responsibility: Otto Kinne,

Oldendorf/Luhe, Germany
Ecological responses to recent climate change. Nature 416:389-395

Weimerskirch H, Cherel Y (1998) Feeding ecology of shorttailed shearwaters: breeding in Tasmania and foraging in the Antarctic? Mar Ecol Prog Ser 167:261-274

Wespestad V, Fritz LW, Ingraham JW, Megrey BA (2000) On relationships between cannibalism, climate variability, physical transport, and recruitment success of Bering Sea walleye pollock (Theragra chalcogramma). ICES J Mar Sci 57:272-278

Winder M, Schindler DE (2004) Climate change uncouples trophic interactions in an aquatic ecosystem. Ecology 85: $2100-2106$

Wingfield JC (1993) Control of testicular cycles in the Song Sparrow, Melospiza melodia melodia: interaction of photoperiod and an endogenous program? Gen Comp Endocrinol 92:388-401

Wingfield JC, Hahn TP, Levin R, Honey P (1992) Environmental predictability and control of gonadal cycles in birds. J Exp Zool 261:214-231

Winkel W, Hudde H (1997) Long-term trends in reproductive traits of tits (Parus major, P. caeruleus) and pied flycatchers Ficedula hypoleuca. J Avian Biol 28:187-190

Winkler DA, Dunn PO, McCulloch CE (2002) Predicting the effects of climate change on avian life-history traits. Proc Natl Acad Sci USA 99:13595-13599

Wooton RJ (1998) Ecology of teleost fishes, 2nd edn. Chapman \& Hall, London

Wuethrich B (2000) How climate change alters rhythms of the wild. Science 287:793-795

Submitted: July 12, 2006; Accepted: January 23, 2006

Proofs received from author(s): March 12, 2007 